\begin{tabular}{|c|c|c|}
\hline 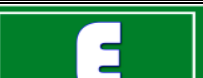 & International Journal of Current Research in & \\
\hline & Biosciences and Plant Biology & \\
\hline $\begin{array}{l}\text { EXCELLENT } \\
\text { PUBLISHERS } \\
\end{array}$ & $\begin{array}{c}\text { ISSN: 2349-8080 (Online) } \bullet \text { Volume } 3 \bullet \text { Number } 9 \text { (September-2016) } \\
\text { Journal homepage: } w \text { ww.ijcrbp.com }\end{array}$ & \\
\hline
\end{tabular}

\title{
Allelopathic Potential of Aqueous Extracts of Various Parts of Plumbago zeylanica L. on Germination and Seedling Growth of Andrographis paniculata Nees.
}

\author{
C. Alagesaboopathi* \\ Department of Botany, Government Arts College (Autonomous), Salem-636 oo7, Tamil Nadu, India \\ *Corresponding author.
}

\begin{abstract}
A b s t r a ct
The present study was conducted to investigate the allelopathic potential of Plumbago zyelanica L. which showed inhibitory effects on seed germination, root length and shoot length of medicinal plant Andrographis paniculata Nees. Leaf, stem and root aqueous extracts of $P$. zeylanica at $5 \%, 10 \%, 15 \%, 20 \%$ and $25 \%$ concentration were applied to determine their effect on seed germination and seedling growth of A. paniculata under laboratory conditions. Results notable that seed germination, root length, shoot length, fresh weight and dry weight of $A$. paniculata were significantly decreased by leaf, stem and root extracts compared with control treatments. Roots were large affected than shoots. Root extracts was more reduced than leaf and stem extract. These outcomes revealed that the inhibitory and stimulatory effect potentialities may be due to the presence of these allelochemicals like alkaloids, tannins, phenols, terpenoids and steroids etc. in the aqueous leaf, stem and root extracts of $P$. zeylanica from the present investigation.
\end{abstract}

\section{Article Info}

Accepted: 05 August 2016

Available Online: 06 September 2016

Ke y w o r d s

Allelopathic effect Andrographis paniculata

Aqueous extract

Germination

Plumbago zeylanica

\section{Introduction}

The term allelopathy derives from two separate words. They are allelon which means "of each other", and pathos which means "to suffer". Allelopathy is also regarded as a biochemical warefare. Allelopathy refers to the chemical inhibition of one species by another. The "inhibitory" chemical is released into the soil environment where it affects the growth and development of neighbouring plants. Allelopathic chemicals can be present in any part of the plant. They can be found in leaves, stems, roots, flowers, fruits, seeds, pollen, rhizomes and stem bark or sometimes found in just one or two of such organs (Zeng et al., 2008). They can also be found in the surrounding soil. These toxins affect target species in several various ways. The toxic chemicals may suppress shoot/root development, they may inhibit nutrient uptake, or they may attack a naturally occurring symbiotic relationship thereby destroying the plant's available principle of a nutrient (Conn, 1980).

Commonly the allelopathy is accepted as notable ecological factor in determining the chemistry of plant communities (Seigler, 1996). Some plants are known to have inhibitory effects on seed germination and seedling growth of other neighbouring plants by either releasing allelopathic substances as exudates from living plant tissues or through decomposition of plant residues (Rice, 1984; Maibam et al., 2011; Butnariu, 2012). Mathela (1994) reported that the secondary metabolites such as alkaloids, tannins, flavonoids, phenolics acid, lignins and coumarins of some for allelopathic action. Likewise, Alagasaboopathi (2014) studied allelopathic potential of 
medicinal plant Erythroxylum monogynum, which noted inhibition on germination and seedling growth of Solanum lycopesicum Mill. Var. PKM-1. Rahimi et al. (2015) reported allelopathic effect of medicinal plants Artemisia annua, Rosmarinus officinalis and Lavandula vera, which showed inhibition in germination and seedling growth of Portulaca oleraceae.

Allelopathy is not a cause of disagreement any more as various methods are usable to evaluate the allelopathic effect of several medicinal plants, highlighting the purpose of allelopathy with the corresponding biological manage of herb and enhance crop productivity (Khan et al., 2009). Alagesaboopathi and Deivanai (2011) reported that as the concentration of extracts of Sesbania grandiflora increased, the growth of the plant decreased. Oluwafemi Ademiluyi Benson (2013) observed that leaf extract of Moringa oleifera significantly decreased germination and seedling growth in Euphorbia heterophylla.

Vaithiyanathan et al. (2014) studied allelopathic effect of Azadirachta indica, which showed inhibition in germination and seedling growth of Abelmoschus esculentus. There are many studies allelochemicals from this plant negatively concern plants such as Azadirachta indica, Pithecellobium dulce, Bauhinia racemosa, Withania somnifera and Centella asiatica (Shruthi et al., 2014; Chakaravarty and Yadava, 2015; Chandra et al., 2012; Alagesaboopathi, 2010).

Plumbago zeylanica $\mathrm{L}$. is a medicinal perennial herb of family Plumbaginaceae, commonly called lead war, Lead wort in English. The plant has many vernacular names in the country viz. Chira, Chitra, Chitramol (in Hindi), Agni, Vahni (in Sanskrit), Chitrakmula (in Gujarati), Chitramula (in Kannada), Vellakeduveli (in Malayalam), Chitramulam (in Telugu), Chitramoolam, Kodiveli (in Tamil).

The root is used as dysentery, laxative, expectorant, abortifacient and in astringent (Kirtikar and Basu, 1993; Chetty et al., 2006). Tincture of root barks is utilized as antiperiodic. The leaves are used as antiperiodic. The leaves are used as scabies, antimicrobial properties and in aphrodisiac. (Krishnaswamy et al., 1980; Dhale and Markandeya, 2011). Its roots are used in traditional system of medicine to treat several diseases like body pain, fever, inflammation and headache (Mittal et al., 2010).

P. zeylanica roots were noted to possess hypolipidemic, antioxidant, anti artherosclerotic, central nervous system stimulant and anti-fertility activities (Kirtikar and Basu, 1975; Mallikadevi and Paulsamy, 2010). Pharmacological findings have indicated that $P$. zeylanica extracts hapatoprotective (Rajesh et al., 2009), antimicrobial (Dhale and Markandeya, 2011), anti-fertility (Edwin et al., 2009) and anti-inflammatory activities (Dang et al., 2011). P. zeylanica have been notable for its anticancer properties (Hiradeve et al., 2010). The various parts of $P$. zeylanica are used as medicine for several disorders and illness. Hence, in this investigation was carried out to achieve the allelopathic potential of $P$. zeylanica aqueous leaf, stem and root extracts on the seed germination and seedling growth of A. paniculata. This is the first report on allelopathic effect of $P$. zeylanica on the germination and seedling development of important medicinal plant A. paniculata. This study was conducted under laboratory experiments.

\section{Materials and methods}

Mature fresh leaves, stem and roots of Plumbago zeylanica were collected in December 2014, from the natural population, Kanjamalai Hills, Salem district of Tamilnadu, India. The freshly collected leaves, stem and roots were washed thoroughly in tap water, shade dried at room temperature $\left(30^{\circ} \mathrm{C}\right)$ for 15 days, then powdered in grinders and sieved. For leaf, stem and root extract, $25 \mathrm{~g}$, leaf, stem and root powder was soaked in $100 \mathrm{ml}$, double distilled water for $24 \mathrm{hrs}$ to get $25 \%$ extract. By dilutions with double distilled water $5,10,15,20$ and $25 \%$ concentrations of extracts were prepared.

The seeds of Andrographis paniculata Nees selected for the present research were collected from Jagir Ammapalayam, Salem, Tamilnadu, India. The seeds of Andrographis paniculata (Tamil - Nilavembu, Sirayangangai, Periyanangai, Shiratkiuchchi; English The Creat, King of bitters) were surface sterilized with $0.1 \%$ mercuric chloride for $1 \mathrm{~min}$. to remove the fungal spores on the seeds. Then the seeds were washed with double distilled water for many times to remove the mercuric chloride. The seeds were soaked in various concentrations of extracts for $24 \mathrm{hrs}$. The experiment was done in $11 \mathrm{~cm}$ dia Petri dishes lined with sterile cotton. Each Petri dish contained 10 regular sized seeds, while seeds in double distilled water were maintained as control separately which were irrigated with $15 \mathrm{ml}$ of distilled water on alternative days. The experimental plan was a randomized complete block with three replicates for each treatment and control. Measurement of germination percentage, root and shoot length, fresh weight and dry weight were carried out using standard 
techniques. Each treatment of this experiment was carried out with three replications and repeated two times. The data obtained were analysed by factorial analysis of variance (ANOVA) to assure significant $(p<0.05)$ effects.

\section{Results and discussion}

In the present study leaf, stem and root extracts of $P$. zeylanica suppressed the seed germination of $A$. paniculata. Complete inhibitory results were notable with concentrated root extracts. Full inhibition (100\%) was noted with concentrated root extracts. Leaf and stem aqueous extracts of $P$. zeylanica on $A$. paniculata proved a moderate reduction in whole parameters. The lessening in percent $A$. paniculata seed germination in the leaf aqueous extract treatments ranged between 30 to $75 \%$ compared to $90 \%$ germination in the control. The lessen in germination percentage of $A$. paniculata seed germination in the $P$. zeylanica stem aqueous extract treatments ranged between 32 to $70 \%$ compared to $93 \%$ germination in the control.
Total inhibitory effect was recorded with concentrated root extracts (Table 1). The seed germination, root and shoot length was reduced in entire concentration (Tables 2-3). The lessen was concentration dependent. The aqueous extracts of two extracts also delayed the shoot lengths of A. paniculata (Tables 2-3). The degree of retardation also raised with extends in the concentrations of the extracts. Statistical analysis at 5\% level (t-test) showed that, apart from comparison between 5 and $25 \mathrm{~g}$ extract concentrations, there were not any significant differences in the growth length of root in the varying extract concentrations as well as those of the control in stem and leaf extracts. The extracts of $P$. zeylanica also induced essential reduction in seedling development of A. paniculata. The extract not only reduced the shoot and root length of $A$. paniculata seedlings but also decreased the fresh and dry weight. The reduction in the fresh and dry weight may be due to stunted and scanty vegetative development of A. paniculata seedling. This reduction may be due to phytotoxic performance of phytochemicals exhibit in aqueous extracts of $P$. zeylanica.

Table 1. The effects of Plumbago zeylanica L. aqueous extracts of root on germination and seedling growth of Andrographis paniculata Nees.

\begin{tabular}{llllll}
$\begin{array}{l}\text { Treatment with } \\
\text { plant Extract }\end{array}$ & Germination $(\%)$ & $\begin{array}{l}\text { Shoot length } \\
(\mathbf{c m} .)\end{array}$ & Root length $(\mathbf{c m})$ & Fresh weight (g.) & Dry weight (g.) \\
\hline Control & $91 \pm 2.7$ & $4.3 \pm 0.3$ & $1.5 \pm 0.1$ & $0 \pm 0.22$ & $0 \pm 0.021$ \\
$5 \%$ & - & - & - & - & - \\
$10 \%$ & - & - & - & - & - \\
$15 \%$ & - & - & - & - & - \\
$20 \%$ & - & - & - & - & - \\
$25 \%$ & - & - & - & - & - \\
\hline
\end{tabular}

$(-)=$ Indicate the absence of germination, shoot length, root length, fresh weight and dry weight.

The results of current research noted that the leaf, stem and root extracts of $P$. zeylanica was inhibitory in $A$. paniculata. These results are comparable to that observed in various reports that notable that roots are greater sensitive to allelochemicals than shoots (Meksawat and Pronprom, 2010). Allelochemicals activity of plants is measured by the sensitivity of roots in the bioassay. The findings are in connection with previous studies reporting that effectiveness of receiver plants to allelochemical was concentration dependent of inhibitory principles with a confirmation threshold (Ashrafi et al., 2009). Furthermore, the permeability of allelochemicals to root tissue was notable to be greater than that to shoot tissue (Nishida et al., 2005).

Table 2. The effects of Plumbago zeylanica L. aqueous extracts of leaf on germination and seedling growth of Andrographis paniculata Nees.

\begin{tabular}{llllll}
\hline $\begin{array}{l}\text { Treatment with } \\
\text { plant Extract }\end{array}$ & Germination $(\boldsymbol{\%})$ & $\begin{array}{l}\text { Shoot length } \\
(\mathbf{c m})\end{array}$ & Root length $(\mathbf{c m})$ & Fresh weight (g.) & Dry weight $(\mathrm{g.})$ \\
\hline Control & $90 \pm 2.5$ & $4.1 \pm 0.6$ & $1.49 \pm 0.7$ & $0 \pm 0.22$ & $0 \pm 0.18$ \\
$5 \%$ & $75 \pm 3.1$ & $3.4 \pm 0.4$ & $1.3 \pm 0.5$ & $0 \pm 0.23$ & $0 \pm 0.13$ \\
$10 \%$ & $50 \pm 6.4$ & $3.8 \pm 0.3$ & $1.3 \pm 0.2$ & $0 \pm 0.12$ & $0 \pm 0.01$ \\
$15 \%$ & $45 \pm 1.3$ & $3.1 \pm 0.5$ & $1.2 \pm 0.4$ & $0 \pm 0.15$ & $0 \pm 0.13$ \\
$20 \%$ & $35 \pm 1.5$ & $2.4 \pm 0.2$ & $1.2 \pm 0.3$ & $0 \pm 0.12$ & $0 \pm 0.16$ \\
$25 \%$ & $30 \pm 1.4$ & $2.1 \pm 0.7$ & $1.1 \pm 0.5$ & $0 \pm 0.10$ & $0 \pm 0.15$ \\
\hline
\end{tabular}


Table 3. The effects of Plumbago zeylanica L. aqueous extracts of stem on germination and seedling growth of Andrographis paniculata Nees.

\begin{tabular}{llllll}
\hline $\begin{array}{l}\text { Treatment with } \\
\text { plant Extract }\end{array}$ & Germination $(\%)$ & $\begin{array}{l}\text { Shoot length } \\
(\mathbf{c m})\end{array}$ & Root length $(\mathbf{c m})$. & Fresh weight (g.) & Dry weight $($ g.) \\
\hline Control & $93 \pm 1.3$ & $4.9 \pm 0.5$ & $1.6 \pm 0.3$ & $0 \pm 0.31$ & $0 \pm 0.023$ \\
$5 \%$ & $70 \pm 5.2$ & $4.6 \pm 0.3$ & $1.5 \pm 0.2$ & $0 \pm 0.14$ & $0 \pm 0.013$ \\
$10 \%$ & $55 \pm 4.7$ & $3.2 \pm 0.6$ & $1.1 \pm 0.4$ & $0 \pm 0.12$ & $0 \pm 0.012$ \\
$15 \%$ & $50 \pm 3.5$ & $3.3 \pm 0.4$ & $1.5 \pm 0.3$ & $0 \pm 0.14$ & $0 \pm 0.013$ \\
$20 \%$ & $45 \pm 4.1$ & $3.0 \pm 0.2$ & $1.6 \pm 0.4$ & $0 \pm 0.12$ & $0 \pm 0.010$ \\
$25 \%$ & $32 \pm 2.6$ & $2.9 \pm 0.1$ & $1.4 \pm 0.3$ & $0 \pm 0.13$ & $0 \pm 0.011$ \\
\hline
\end{tabular}

The aqueous leaf, stem and root extracts of $P$. zeylanica indicated inhibitory results on seed germination, shoot length, root length, fresh weight and dry weight of $A$. paniculata. The $P$. zeylanica leaf, stem and root extracts suppressed the germination and growth of A. paniculata in the current investigation. Hence, the must have been sure for the inhibition of seed germination, development and dry matter collection of shoot and root of the plant were progressively decreased with the higher in the concentration of the extract. Further investigations are want to isolate and characterize the supposed allelochemicals in P. zeylanica and the interaction that could be pointing out for the noted inhibition of seed germination and plant development.

\section{Conclusion}

Raised concentration of $P$. zeylanica leaf, stem and root aqueous extract negatively influenced seed germination, root length, shoot length and seedling fresh weight and dry weight of $A$. paniculata propose that the plant has allelopathic effect and assimilate allelochemicals. These allelochemicals could be the vital intention for the restricted development of other plant species near their colony. Isolation and characterization of those allelochemicals from $P$. zeylanica could be demonstration as manage for the development of biodegradable, environment friendly invention genuine herbicides and substitute it for chemical herbicides for sustainable weed regulate. However, larger investigation is wanted to further convince the allelopathic potentialities of $P$. zeylanica and laboratory and field experiments.

\section{Conflict of interest statement}

Authors declare that they have no conflict of interest.

\section{References}

Alagesaboopathi, C., 2010. Allelopathic effect of Centella asiatica aqueous extracts on Pearl Millet (Pennisetum typhoides L.) and Cow Pea (Vigna unguiculata Walp.). Pak. J. Weed Sci. Res. 16(1), 67-71.
Alagesaboopathi, C., 2014. Allelopathic effect of aqueous extract of Erythroxylum monogynum Roxb. on germination and growth of Solanum lycopersicm Mill. Var. PKM-1. Int. J. Sci. Res. 3(8), 1091-1094.

Alagesaboopathi, C., Deivanai, M., 2011. Allelopathic potential of Sesbania grandiflora Pers. on germination of Cajanus cajan Millsp. (Red gram) varieties. Int. J. Biosci. 1(5), 51-55.

Ashrafi, Z.Y., Sadeghi, S., Alizade, H. M., Mashhadi, E.R., Mohamadi, E. R., 2009. Study of bioassay the allelopathical effect of neem (Azadirachta indica) nhexane, acetone and water soluble extracts on six weeds. Int. J. Biol. 1, 71-77.

Butnariu, M. 2012. Analysis of Sorghum halepense's behavior in presence of tropane alkaloids from Datura stramonium extracts. Chem. Central J. 6, 1-7.

Chakaravarty, A., Yadava, R.N., 2015. Allelopathic activity of Leguminosae plants. Int. J. Sci. Res. 4(2), 2345-2346.

Chandra, S., Chatterjee, P., Dey, P., Bhattacharya, S., 2012. Allelopathic effect of ashwagandha against the germination and radicle growth of Cicer arietinum and Triticum aestivum. Pharmacogn. Res. 4(3), 166-169.

Chetty, K.M., Sivaji, K., Sundarsanam, G., Sekar, P.H., 2006. Pharmaceutical studies and therapeutic uses of Plumbago zeylanica L. root. Ethnobot. Leaflets. 10, 294-304.

Conn, E.E., 1980. Cyanogenic compounds. Annu. Rev. Plant Physiol. 31, 433-452.

Dang, G.K., Parekar, R.R., Kamat, S.K., Scindia, A.M., Rege, N.N., 2011. Anti- inflammatory activity of Phyllanthus emblica, Plumbago zeylanica and Cyperus rotundus in acute models of inflammation. Phytother. Res. 25(6), 904902.

Dhale, D.A., Markandeya, S.K., 2011. Antimicrobial and Phytochemical screening of Plumbago zeylanica Linn. (Plumbaginaceae) leaf. J. Exp. Sci. 2(3), 4-6.

Edwin, S., Joshi, S.B., Jain, D.C., 2009. Antifertility activity of leaves of Plumbago zeylanica in female albino rats. Eur. J. Contracept. Reprod. Healtcare. 14(3), 233-239.

Hiradeve, S., Danao, K., Kharabe, V., Mendhe, B., 2010. Evaluation of anticancer activity of Plumbago zeylanica Linn. leaf extract. Int. J. Biomed. Res. 1(2), 1-9.

Khan, A.L., Hussain, J., Hamayun, M., Shinwari, Z.K., Khan, H., Kang, Y., Kang, S., Lee, I., 2009. Inorganic profile and allelopathic effect of endemic Inula koetzii from Himalaya Pakistan Pak. J. Bot. 41(5), 2517-2527. 
Kirtikar, K.R., Basu, B.D., 1993. Indian Medicinal Plants. Volume 2. Shiv Publishers, Dehra Dun, India.

Kirtkar, K.R., Basu, B.D., 1975. Indian Medicinal Plants. Jayyed Press, New Delhi.

Krishnaswamy, M., Purushothaman, K. K., 1980. Plumbagin: A study of its anticancer, antibacterial and antifungal properties. Ind. J. Exp. Biol. 18(8), 876-877.

Maibam, R.D., Meenakshi, B., Paul, S.B., Shrma, G.D., 2011. Neurotoxic and medicinal properties of Datura stramonium L. - Review. Assam Univ. J. Sci. Technol.: Biol. Environ. Sci. 7(1), 139-144.

Mallikadevi, T., Paulsamy, S., 2010. Plumbago zeylanica - a potential plant for antimicrobial activity. Plant Arch. 10, 547-550.

Mathela, C.S., 1994. Allelochemicals in medicinal and aromatic plants. In: Allelopathy in Agricultural and Forestry (Eds.: Narwal, S. S., Tauro, P.). Scientific Publishers, Jodhpur, India. pp.213-228.

Meksawat, S., Pornprom, T., 2010. Allelopathic effect of itchgrass (Rottboellia cochinchinensis) on seed germination and plant growth. Weed Biol. Manage. 10, 16-24.

Mittal, V., Sharma, S.K., Kaushik, D., Khatri, M., Tomar, K., 2010. A comparative study of analgesic activity of Plumbago zeylanica Linn. Callus and root extracts in experimentals mice. Res. J. Pharm. Biol. Chem. Sci. 1, 830-836.

Nishida, N., Tamotsu, S., Nagata, N., Saito, C., Sakai, 2005. Allelopathic effects of volatile monoterpenoids produced by Salvia leucophylia: Inhibition of cell proliferation and DNA synthesis in the root apical meristem of Brassica campestris seedlings. J. Chem. Eol. 31, 1187-1203.

Oluwafemi Ademiluyi Benson, 2013. Allelopathic effects of Moringa oleifera on the germination and seedling survival of Euphorbia heterophylla L. Bull. Pure Appl. Sci.Botany. 32b(2), 77-83.

Rahimi, M., Bidarnamani, F., Shabanipoor, M., 2015. Effects of allelopathic three medicinal plants on germination and seedlings growth of Portulaca oleraceae. Biol. Forum Int. J. 7(1), 1520-1523.

Rajesh, K., Sushkil, K., Arjun, P., Jayalakshmi, S., 2009. Hepatoprotective activity of aerial parts of Plumbago zeylanica Linn. against carbon tetrachloride induced hepatotoxicity in rats. Int. J. Pharm. Pharmaceut. Sci. 1(Suppl.1), 171-175.

Rice, E.L., 1984. Allelopathy. $2^{\text {nd }}$ Edition, Academic Press Inc., Orlando. pp.422-424.

Seigler, D.S., 1996. Chemistry and mechanisms of allelopathic interactions. Agron. J. 88, 876-885.

Shruthi, H.R., Hemanth Kumar, N.K., Shobha, J., 2014. Allelopathic potentialities of Azadirachta indica A. Juss. aqueous leaf extract on early seed growth and biochemical parameters of Vigna radiata (L.) Wilczek. Int. J. Latest Res. Sci. Technol. 3(3), 109-115.

Vaithiyanathan, T., Soundari, M., Rajesh, M., Sankar Ganesh, K., Sundaramoorthy, P., 2014. Allelopathic effect of Azadirachta indica L. on the germination of Abelmoschus esculentus L. Int. Lett. Natural Sci. 15, 13-22.

Zeng, R.S., Malik, A.V., Luo, S.M., 2008. Allelopathy in Sustainable Agriculture and Forestry. Springer Verlag, Germany. 412p.

\section{How to cite this article:}

Alagesaboopathi, C., 2016. Allelopathic potential of aqueous extracts of various parts of Plumbago zeylanica L. on germination and seedling growth of Andrographis paniculata Nees.. Int. J. Curr. Res. Biosci. Plant Biol. 3(9), 46-50. doi: http://dx.doi.org/10.20546/ijcrbp.2016.309.006 